\title{
ADAPTIVE STRATEGIES EMPLOYED BY THE MICE SECTOR IN RESPONSE TO COVID-19
}

\author{
Refiloe Julia LEKGAU \\ University of Johannesburg, School of Tourism \& Hospitality, College of Business and Economics, South Africa, e-mail: rlekgau@uj.ac.za \\ Tembi Maloney TICHAAWA* \\ University of Johannesburg, School of Tourism \& Hospitality, College of Business and Economics, South Africa, e-mail: tembit@ uj.ac.za
}

\begin{abstract}
Citation: Lekgau, R.J., \& Tichaawa, T.M. (2021). ADAPTIVE STRATEGIES EMPLOYED BY THE MICE SECTOR IN RESPONSE TO COVID-19. GeoJournal of Tourism and Geosites, 38(4), 1203-1210. https://doi.org/10.30892/gtg.38427-761
\end{abstract}

\begin{abstract}
COVID-19 has brought to the fore drastic and transformative changes to MICE tourism. The current study therefore sought to examine the adaptive responses employed by the MICE sector of South Africa to survive and maintain business continuity during the COVID-19 pandemic. Adopting a qualitative research design, 19 representatives of various subsectors of the MICE industry (including organisers, suppliers, and associations) were interviewed. The data reveals that the immediate strategies implemented by many MICE organisations involved the reevaluation of their operational costs. Moreover, the study found that the sector has readjusted its business models to include virtual events in order to ensure recovery and resilience in light of the pandemic. The study argues the importance of understanding adaptive strategies as broadening theory on tourism and crises (specifically to the MICE sector) as well as understanding the process of sector resilience post-COVID-19.
\end{abstract}

Key words: MICE tourism, virtual events, COVID-19, resilience theory, South Africa

\section{INTRODUCTION}

The disruption and ensuing economic impact of COVID-19 on the global tourism system has emerged as a prominent theme in the past two years (Dube et al., 2021; Fu, 2020; Korinth and Ranasinhe, 2020; Matei et al., 2021). While travel and tourism activities have been viewed as significant contributors to the spread of the virus (Sigala, 2020), strong proponents of the industry contend that tourism is significant for economic recovery owing to the resilience it has shown in the past to crises and disasters (United Nations World Tourism Organisation [UNWTO], 2020; Cheng and Zhang, 2020). Indeed, prior to the pandemic, tourism had been one of the leading sectors for economic growth and development in the world. Consequently, there have been some investigations into the recovery and resilience of the tourism industry (Fu, 2020; Quang et al., 2020; Mensah and Boakye, 2021; Ntounis et al., 2021; Su et al., 2021; Matei et al., 2021). In fact, the UNWTO (2020) recommended resilience learning as one of the key strategies for future tourism development so as to ensure survivability and sustainability in the sector. Accordingly, the current study adopts the resilience theory as the theoretical basis through which to understand how tourism sectors have adapted and coped with COVID-19. Although originally developed in the field of natural sciences, the theory of resilience has been used to understand the manner in which tourism systems (such as organisations, communities and destinations) respond to exogenous shocks and disasters (Biggs et al., 2012; Espiner et al., 2017; Kato, 2018).

The current study draws focus to the meetings, incentives, conferences (and conventions) and exhibitions sector, widely referred to as MICE tourism. Pre-COVID-19, MICE tourism had been one of the leading contributors to tourism growth, with the Event Safety Council (2020) reporting that the sector contributed US\$ 1.5 trillion to the global GDP and supported approximately 25.9 million jobs. In the context of developing regions, such as Sub-Saharan Africa, this form of tourism accounts for approximately 25\% of international tourist arrivals (Christie et al., 2013). Despite this however, the sector has been relatively unexplored in tourism literature, especially in the Sub-Saharan African contexts (Rogerson, 2015; Tichaawa, 2017; Marais et al., 2017). Arguably, in light of the emerging studies on tourism and COVID-19, MICE tourism similarly remains a largely unexplored facet of tourism. As such, the current study seeks to address this omission in research by exploring the South African MICE sector, as the country had been one of the leading MICE destinations in Sub-Saharan Africa prior to the pandemic (Marais et al., 2017). Similar to other global events industries, the events sector was one of the first forms of tourism to be regulated and restricted in South Africa upon the arrival of the COVID-19 virus in the country and the subsequent declaration of the state of disaster (in March 2020) which led to the mass cancellation of all major events in the first half of 2020 (Hemmonsbey et al., 2021). Notably, the second half of 2020 saw a shift from event cancellation to event preparations and the strategic planning of hosting events during the pandemic as COVID-19 regulations in the country began to ease. As such, the current study aims to explore the response strategies employed by the MICE sector of South Africa in light of COVID-19. The current study is grounded by the premise that the response strategies determine the ability of the MICE sector to survive, adapt and ensure their resilience post-pandemic. Therefore, the current study provides a preliminary analysis of the MICE sector's resilience to COVID-19. This study concurs with the contention of Alsono et al. (2021) that studies focusing on the adaptation of tourism industries to the unpredictability of COVID-19 are invaluable since the impacts of the pandemic have yet to be fully understood, particularly in the context of MICE tourism.

\footnotetext{
* Corresponding author
} 


\section{LITERATURE REVIEW}

\section{Resilience theory}

In light of the current circumstances, resilience theory has emerged as a prominent theme in tourism literature. Ntounis et al. (2021) however underscores that literature tends to lack an agreed upon definition of resilience since the concept has been adopted across various disciplines. Bhamra et al. (2011) avers the various definitions of resilience to include two factors: (i) the systems' robustness (or resistance) to unexpected external shocks and disruptions, and (ii) the ability of these systems to recover, or bounce back. Generally, the resilience theory relates to the capacity of tourism systems to effectively deal with disasters and crises (Jaaron et al., 2021). Within the sustainable tourism development paradigm, resilience thinking has been described to concern maintaining the business operations and capacity of tourism businesses (and destinations) to ensure a return to a desirable state following exogenous shocks (Derissen et al., 2011). One of the core differences between the disciplinary definitions of resilience relates to their different viewpoints on stability, or the state of equilibrium.

The state of equilibrium refers to the ability of systems to maintain operations - i.e. the performance of key functions, during periods of crisis (Clement and Rivera, 2017). One set of resilience definitions view resilience as the capacity of systems to return back to pre-crisis state (i.e. to bounce back), while another set of definitions acknowledge crisis to force systems over a certain threshold of change, consequently forming a new state or form (Knight-Lenihen, 2016; BasurtoCedeno and Pennington-Gray, 2018; Chowdhury et al., 2019; Kaufmann, 2013). In this latter case, the crises creates a 'new normal' (Basurto-Cedeno and Pennington-Grat, 2018). In the context of the current study, resilience therefore relates to the ability of the MICE sector to adapt to the new normal, as the scale and magnitude of the COVID-19 pandemic had led to long term structural changes in the tourism environment. Accordingly, inasmuch as industries' reports and the government reports often relate recovery to pre-COVID-19 growth statistics, the nature and characteristics of tourism will undoubtably be altered going forward owing to the socio-economic, political and psychological effects of the pandemic. Ntounis et al. (2021) highlight that existing research into resilience has often focused on natural disasters, climate change, economic downturns and/or terrorist attacks, leaving scant application of the theory to health crises, particularly disease outbreaks. As such, the study conforms with the assertion of Lew (2014) on the importance of context when examining resilience. Similarly, Fromhold-Eisebith (2015) adds that the resilience, and dynamics affecting resilience, differs between industry sectors, therefore, when exploring the resilience of the MICE sector, it becomes paramount to unpack the nature and characteristic of the sector, pre-COVID-19, as well as to examine the current COVID-19 measures affecting the sector in late 2021.

\section{MICE tourism}

MICE tourism, which is considered one of the oldest forms of travel, owes much of its growth to globalization (Davidson and Cope, 2003; Rogerson, 2015). Indeed, the sector has been noted to be an articulation of the global economy (Buathong and Lai, 2017). Such assertions have been supported by various reasons, including the interconnectedness of industries as well as the growth and expansion of travel and information technology (Marques and Pinho, 2021; Rogerson, 2015; Draper et al., 2018). Notably, business travel has become a core part of many, if not all, sectors of the economy as it relates to knowledge and business expansion. In fact, some authors posit the importance of exploring both the tourism and non-tourism effects of business travel in destinations in order to gain a comprehensive understanding of the sector. It is unfortunate that very few studies have gone on to discuss the importance of MICE tourism from a non-tourism perspective (Davidson, 2019; Rogerson, 2015). Generally, this form of tourism caters to three key markets (corporate, associations and buyers) in order to educate, motivate, network and/or sell to other markets (Draper et al., 2018). Focusing on their fundamental role to the network society and knowledge-based economies, Rogerson (2015) avers MICE tourism to be crucial in meeting the increased need for knowledge transfer, thereby advancing knowledge based societies. Additionally, Jago and Deery (2010) argue that the role of this sector of tourism is for improving business performance by emphasising how it serves to underpin innovation. Expanding on the role of the MICE sector, Bartis et al. (2021) report that these events are important platforms for trade and interactions amongst businesses. In this regard, the authors thus affirm their contribution to the advancement of an economic sector as well as its value chain. Evidently, while tourism is the beneficiary for the operations of the MICE sector, this sector exists to achieve the specific objectives of organisations (Jago and Deery, 2010). Against the backdrop of the reasons outlined above, the MICE sector had long been considered a key area for growth in global tourism industries (Buathong and Lai, 2017; Bartis et al., 2021). This had been realized by the immense infrastructural developments (mostly facilities and transportation) which provide for the sector, thereby making it an important aspect of urban development (Rogerson, 2015; Buathong and Lai, 2017). Other studies have drawn specific attention to this distinctive market, owing to its greater than normal spend (especially compared to leisure tourists), and its limited seasonality in travelling (Bueno et al., 2020; Cassar et al., 2020). Additionally, since MICE tourism facilitates core functions of organisations, Fenich (2008) contends its relative resilience in times of crises. For these reasons, amongst others, MICE tourism has become known to increase the competitiveness of tourism destinations (Cassar et al., 2020; Alananzeh et al., 2019). Affirming such assertions, Nicula and Elena (2014) note that the sector offers opportunities for diversification of the tourism experience, especially from the natural and anthropogenic elements of destinations that have long attracted international tourists.

\section{MICE tourism in South Africa and COVID-19}

In the specific case of South Africa, MICE tourism has been described as an important contributor to the country's tourism growth (Donaldson, 2013; Fenich et al., 2012). South Africa is a globally competitive MICE destination, with the country having a long history of hosting several international and major events including the 2002 World Summit on Sustainable Development, the 2006 World Economic Forum, 2011 United Nations Climate Change Conference and the 2018 BRICS Summit (Marais et al., 2017). In addition, the importance of the sector has been further solidified by the 
country's international ranking as a MICE destination (Marais et al., 2017). Evidently, this is a significant economic sector in the country on which the country had sought to capitalize through several interventions, including the establishment of the national convention bureau in 2012, the development of world-renowned convention and hotel facilities, as well as the improvement of transportation networks (Rogerson, 2015; Donaldson, 2013; Fenich et al., 2012). This consequently confirms the aforementioned views on the link between urban development and MICE tourism (Fenich et al., 2012).

While the sector had been performing impressively before the pandemic, the onset of the COVID-19 (and the subsequent measures taken by the South African government) severely impacted the operations of events in the country (Hemmonsbey et al., 2021). The local safety measures implemented in order to limit the spread of the virus included a national lockdown order, international travel bans (resulting in the grounding of air travel), restrictions on gatherings as well as social distancing measures (Lapointe, 2020; UNWTO, 2020; Kuscer et al., 2021). Ho and Sia (2020) explain that such safety measures implemented by South Africa, as well as by other countries, are a result of confirmation that the main drivers of the spread were population densities as well as the intensity of social contacts. As a result, the events sector was amongst the hardest hit tourism sectors (Dillette and Ponting, 2021; Seraphin, 2021; Ho and Sia, 2020; Steriopoulos and Wrathall, 2021). The national lockdown order within South Africa involved the institution of the National State of Disaster which introduced a varied Alert Level system in order to manage the gradual easing of lockdown restrictions based on the severity of the COVID-19 crisis in the country (Government of South Africa, 2021).

The Alert Level system comprises of 5 Levels in which the fifth level is the most restrictive and the first level means most restrictions on movement, business and social activity are eased. One of the earliest reactions of the tourism industry to the pandemic was the mass cancellation of events, which was sustained throughout most of 2020. Notably however, in South Africa, business travel was one of the first types of travel to be permitted under the COVID-19 regulations (specifically Alert Level 3), and MICE tourism has been identified as one of the key focus areas for recovery in the country (South Africa Travel Trade, 2020; Rogerson and Baum, 2020). Accordingly, this provides a valuable opportunity to explore the adaptive responses of the sector so as to understand the process of recovery for the sector.

\section{METHODOLOGY}

The present study utilizes a qualitative research approach to explore the manner in which respondents have adjusted and responded to the impacts of COVID-19 as well as to the effects of the lockdown measures taken by South Africa. Since qualitative research seeks to understand the research phenomenon, as opposed to predicting its outcome (Tomaszewski et al., 2020), it was deemed most applicable to examine the process of the adaptation of the MICE sector to the COVID-19 tourism environment. Further, owing to the unprecedented nature of the pandemic, and that the subsequent impacts (on tourism) are yet to be fully understood, this research design allows for a rigorous exploration into the subject matter.

Data was collected through a series of interviews with numerous representatives of the local MICE sector. To gain a comprehensive understanding on the sector's response, the study gathered insights from various subsectors of the MICE tourism sector, including MICE planners (such as professional conference organisers [PCO], and exhibition and trade show organisers), national (and provincial) convention bureaus, suppliers (venues, audiovisual [AV] and infrastructure) and government representatives. Finally, views of key industry associations were also considered in the study, which includes the Southern African Association of the Conferences Industry (SAACI), the International Congress and Convention Association (ICCA), Association of African Exhibition Organisers (AAXO), Society for Incentive Travel Excellence (SITE) and the Event Safety Council. In total, 19 interviews were conducted. The interviews comprised of open-ended questions so as to allow for further probing and the exploration of emerging themes. Key questions posed to the study sample centred around their business responses to the pandemic, the measures taken to ensure survival and the adaptation (or plans towards adaptation) to the COVID-19 regulations governing the operations of the MICE sector in South Africa. The data collection process took place from February 2021 to June 2021. However, is it important to note that during this period, the country had been moved from Alert Level 3 to Alert Level 1 (from 1 March 2021) to Alert Level 2 (from 31 May 2021) to Alert Level 4 (from 16 June 2021) (South Africa Government, 2021). Primarily, the movement between Alert Levels meant adjustments on the numbers of people allowed in MICE venues. The data gathered from the interviews were recorded, transcribed and uploaded onto Atlas.ti version 9. The qualitative data analysis software enabled the creation of codes and the grouping of codes from the interview transcripts. This led to the development of key themes, as discussed in the following section.

\section{RESULTS AND DISCUSSION}

\section{Operational strategies}

The initial strategies employed by the MICE sector had been to reexamine their operational costs and implement cuts where necessary. For instance, one respondent, a meetings planner explained that, 'So we were able to implement some immediate strategies to try and cut some overheads and try and just restrict the operating costs'. This came as a result of the economic losses resulting from both the national and international lockdown regulations (Haywood, 2020; Kuscer et al., 2021; Rogerson, 2021), which not only halted the operations of the MICE sector, but also caused much uncertainty around when this form of tourism would resume. In fact, the national lockdown measures of South Africa had begun with an initial 21 days where only essential services of the country were permitted to operate (Bama and Nyikana, 2021; Hemmonsbey et al., 2021; Nyawo, 2020). This meant that most of the working population had to transition to working from home. In response, some members of the MICE sector took the decision to terminate their office lease agreements. To illustrate, some MICE planners detailed that:

'We've also had to let go of our office. So everybody's working remotely, so we no longer have offices, which we had in Century City.'

'We were lucky that we could get out of our contract for our office because we at least didn't have to pay that. So because of that we had offices. So that was quite a chunk of money, that thankfully, the landlord allowed us to get out of there.'

Such delineations indicate that the transition to remote working did provide some opportunities for certain sub-sectors of the MICE industry to cut back on substantial costs, particularly during a period of much economic uncertainty and 
losses. It is important to note that some stakeholders in MICE could opt out of their leases, whereas the impact of lockdown measures on venue providers resulted in different responses. Some respondents had stated that venues had to take the difficult decision to shut their doors until a period of time when MICE events were once again permitted, which concurs with the literature on the economic impact of COVID-19 on tourism businesses.

Unfortunately, the examination process into the organisations' operational budgets led to significant staff cuts and the various subsectors of the MICE sector agreed that this was a common strategy employed. The following responses were taken from venue and AV suppliers, as well as from a MICE event planner:

' $80 \%$ of our staff has been laid off. The staff that we laid off for mostly operational staff, so like guys on the floor who actually run the events, because if there's no events in we don't need those guys to run the events.'

'And then exhibitions companies, organising companies and supply companies, so they either closed temporarily, they've laid off staff, or they've retrenched staff."

'So for example, the Century City Conference Centre used to have 120 staff, now they've got 50 staff.'

The above findings affirm with the available writing on the reactions of tourism businesses to COVID-19 (Rogerson et al., 2021; Giddy and Rogerson, 2021; Steriopoulos and Wrathall, 2021; Dillette and Ponting, 2021). This additionally ties into the devastation of the pandemic to livelihoods, as respondents in the current study (alongside others represented in literature) underscored the importance of the sector to job creation and economic development. However, against the current circumstances, some respondents were of the view that these staff cuts, as dire as they had been, had to be made in order to ensure the survival of the MICE organisations. In fact, a few respondents explained that the failure to take these drastic steps resulted in the closure of some MICE businesses. For instance, one respondent, a trade show organizer, stated as follows:

'As horrible as it is, you need to get rid of staff that are not absolutely critical to the business. And I know of a company that kept the staff on throughout the whole of last year [2020] at full pay, and closed down in January. That is [a] big mistake, because your staffing component is quite often your most costly expense every month. And you know what, that is unfortunately, [but] don't wait, that's the first expense [you] need to get rid of.'

Resultantly, the staff retrenchment led to some major changes to the remaining staff in terms of employment structures (and contracts). The study respondents explained that the present nature of the MICE tourism environment meant that much of the remaining staff had to be put on furlough and so their working hours, and subsequently, their salaries, were significantly less. One meeting planner underlined that, 'And then we reduced staff salaries, because obviously we weren't getting any incoming payments', while another exhibition organiser specified, 'So the biggest thing is that staff that are left are now getting paid 50\% [of their] salaries'. Again, this was a common practice amongst tourism businesses in responding to COVID-19, as there was a sudden decrease (and halt) of income generated from the industry. The adoption of such strategies meant a lack of stability in employment opportunities for the MICE sector, as incoming staff would most likely (for the near future) be placed on temporary contracts. One respondent questioned whether sector recovery would reverse this, suggesting that some MICE organisations may continue with this nature of employment even in the future, contending that, '... it is also going to change the way people work in terms of contract hours going forward.'

Finally, many of the respondents noted the importance of flexibility regarding event cancellations. Similar to the reports on the cancellations of sport events, and cultural events (see for instance Hemmonsbey et al., 2021; Seraphin, 2021; Westmattelmann et al., 2021), early to mid-2020 saw massive cancellations of MICE events in South Africa. Resultantly, a respondent affirmed that 'a lot of clients wanted refunds and we had to accommodate where we could'. In addition, the respondents agreed that the economic crises caused by COVID-19 meant that client organisation could no longer afford to host the events they had planned. One PCO underscored that:

'So the initial thing we did was we had to be a lot more flexible with contracts. So where we would say there would be a non-refundable deposit, we actually had to be a lot more flexible, because it's all about relationships. You know, we couldn't say to clients, 'sorry, we're keeping your money', but yet they're busy struggling and they're not receiving money from their employer. So flexibility in contracts, that was initially huge.'

The importance of maintaining business relationships with clients, and suppliers, was subsequently viewed as an important activity for the sector in order to ensure their continuity for when these events would return.

\section{Postponements rather than cancellations}

While the initial reaction from the MICE market enforced cancellations, the respondents noted that one of the most important actions taken was to ensure the postponement of events, rather than the cancellation. One manager of a MICE venue expressed the following:

'Our immediate impact with that guests had a knee jerk reaction. People wanted to postpone immediately, because initially, we had no idea how long this was going to last. So any conferences that were happening in March, last year, April, May, were put off until sort of June and July and so on. And so that was the immediate impact. And then it started rolling after that, because people wanted to postpone [further].'

Several months into lockdown, there was a rise of virtual events as a medium to ensure continuity in the sector. Interestingly, some respondents noted that:

'And where clients are prepared to pivot, because not all clients are prepared to go virtual. A lot of clients feel that they bid for South Africa to win the bid. They want people to come to South Africa, also in industries where they want to leave a legacy where, a lot of the clients bid for conferences to grow the South African and the African footprint.'

Significantly, the few available writings on COVID-19 and events affirm the major shift to the virtual environment (Dillette and Ponting, 2021; Seraphin, 2021; Westmattelmann et al., 2021). Evidently, the above study illustrates that, in some types of MICE events, there exists the need to have in-person events. The respondents of the study indicated that it was mostly the association market that had decided to wait and postpone in-person events, or turn them into a hybrid model. Accordingly, for this market, it became especially important for the MICE sector of the country to be able to 
postpone such events, hosting them at a later time. It is important to note that the above responses were from MICE event planners and that key MICE role players, such as the convention bureaus, had similarly mentioned the importance of retaining this business. For instance, a representative from the National Convention Bureau explained:

'So we a lot of the work went into trying to convince those clients to rather postpone than to cancel. And all those events, we managed to postpone 28, 12 were cancelled, 5 will sit on virtual platforms.'

It is imperative to consider the implications of the postponement of events, as while such decisions are taken in order to take advantage of the economic, tourism and non-tourism benefits of events, postponing events could also be accompanied by venue challenges in the future. As the respondents affirm that postponement often leads to scheduling challenges for MICE venues. Additionally, the postponing of events had been influenced by the uncertainties around the COVID-19 virus, the emergence of new variants, and periods of rising infections. Moreover, a large share of the respondents did note that the sector had adapted to the virtual environment, which had necessitated a change in business strategy.

\section{Changing business strategy}

Current literature on COVID-19 has affirmed that the pandemic has created several long-term changes to the tourism industry (Giddy and Rogerson, 2021; Lapointe, 2020; Ho and Sia, 2020). For the MICE sector, the initial months of the lockdown meant that the sector had to close down, however there was a massive global shift to the virtual space. Many respondents have highlighted the importance of undertaking research into the new MICE environment, prior to the substantial financial investment. In fact, one respondent, an exhibition organizer, stated:

'I think research is really important because very often, you know, as entrepreneurs, we can have big bad ideas, and we all have these big bright ideas. And we believe that because within our circle, or within our heads, they say, you know, what you see within your circle just gets reinforced and you believe that that is how the whole world thinks. But until you do your research outside your circle, and realise exactly what the true reality is, then only will you be able to find the solutions to deliver on and that's really, really important. So we need to do our research to understand what the needs are because the way forward is going to requires a sustained, a large investment, you know. And if we're going to invest in something, it needs to be able to deliver returns on investment for both our exhibitors, our attendees and us as organisers of the events. So the research is key to that. And then on the research, then you can build in terms of what platforms you need to build, to deliver on those needs.'

Virtual platforms have been relatively unexplored in the South African MICE sector. The transition to virtual (and later hybrid) events had been a major learning curve for the sector. Accordingly, the respondents note that, in a very short time, MICE planners had to adapt to the new virtual environment, while ensuring that the events executed met stakeholders' expectations and the investment involved. The respondents explained that this required research into the various types of virtual platforms in order to determine which would be most effective in the delivery of event objectives. A PCO expressed the following sentiment:

'There are so many technology suppliers around and there are different virtual platforms that I've come across. But not every one of them is equal. And only if you do your homework properly, you see the flaws in each system. And you've got to meet them, you've got to explore it, you got to try the back end, you got to trial it and you got to get your team to trial it, you possibly have to even present it to some of your key clients, your key partners, and get them to trail it to see how comfortable they are to be $100 \%$, because it requires quite a large investment to invest in this and it can go horribly, horribly wrong.'

In line with the importance of research, the respondents indicated that they have had to reevaluate the manner in which they deliver events, owing to the change in mode (i.e. virtual). As such, the study found that the MICE sector focused on understanding the needs of the client organisations, their objectives for their events and how the various virtual platforms can fulfil such needs. For instance:

'But I want to acquire as much information from the very same people that used to buy to me, [and that] give me as much information in terms of what you want, so that I can go and repackage, repurpose my business to meet you to meet your needs.'

Similarly, the majority of the respondents affirmed that their strategy had to change in order to account for the COVID19 pandemic, with one PCO asserting that 'so the whole business model there had to change. We've had to take everything virtually'. Indeed, another respondent added, 'So when COVID happened, the board very quickly realised, well, we're not going to have an event like we normally had'. Such results concur with the prominent theme in literature that contends that the pandemic has led to some major structural changes in the tourism industry. Specifically, for the MICE sector, this includes the adoption to and use of virtual events as a means of hosting events going forward. While virtual events have been around for decades, their widespread adoption has been hindered by their limited capacity to engage with attendees and facilitate interaction (Pearlman and Gates, 2010). The COVID-19 pandemic therefore served to fast-track the development of virtual platforms in order to suit the needs of the MICE sector owing to it being the only available means to host such gatherings.

In addition to the changes in business model, the pandemic also necessitated the development of strategies to cope with the change, as well as to recover from the crises as expressed in the following:

'And then we needed to have a really good commercial strategy, and recovery strategy. And our company, we had that from the beginning and it was clearly communicated, and everyone contributed, because not everything is going to work for every market or every, every hotel, but it was clearly communicated. And they received a lot of feedback from internal teams to be able to carve out what this looks like, and what our recovery road or the road ahead will look like for the next five years.'

As evident in the above, the development of recovery strategies entailed the involvement of all members in the organisation. Similarly, Nguyen et al., (2021) posit staff knowledge and skills in the developing strategies to inform organizational resilience. This has been confirmed by the current study findings to not only gather unique insights from various members in the organisation but to foster collective drive towards the common goal, being the recovery.

\section{Venue-specific responses}

While some venues did close down due to the pandemic, the study found that other venue suppliers (specifically hotels) responded to new market opportunity emerging from the pandemic:

'But there's also opportunities where it is some niche type of business that has come through so like, you know, a 
hybrid, but also where, you know, we've got bio bubbles. You know, we we've, you know, had customers that say, we want to take over the hotel. As a group, we want to take over the hotel. And we want full exclusivity and no one coming through. It's been a lot around sports groups that we've been getting. And they take over the hotel, and then the team that is there, is tested prior to check in. And then you know, they take over the hotel, maybe for a whole week or something. So we've managed to really position ourselves in in a way that we're able to secure these, keep everyone you know, creating confidence that people will be safe and really managing that business. So and this a business that we didn't have before COVID.'

Evidently, for venue suppliers, particularly hotels, an opportunity emerged to tap into a new market during COVID-19. Recent literature on the changes in tourism consumption have demonstrated that COVID-19 greatly increased the perceived fear of travelling (Rogerson and Rogerson, 2021; Wang et al., 2020; Agyeiwaah et al., 2021; Matiza and Slabbert, 2021). The manner in which the virus spreads led to more cautious decision making in travel. Consequently, the hotel venue respondents indicated that this resulted in a new market, termed 'bio bubbles' above, which had first started with sport teams. However, the respondents aver that this practice/opportunity could be an option for the MICE sector in the future, with many of the respondents stating that this could be particularly valuable for the MICE market. More specifically, some respondents postulate that this could be an emerging trend in the incentive travel subsector. On the booking out of small hotels for incentive travels, one respondent representing this subsector, stated that '... that way, they have also got that sense of security. They are not mingling with other people that they don't know where they've been'. However, it is important to disclose that this could be an expensive endeavor for many organisations, particularly in an economy that has been devastated by the pandemic.

Elsewhere, some of the large-scale MICE venues were transformed into COVID-19 hospitals. Among the most prominent examples was the Cape Town International Convention Centre, which operated as such a hospital during the onset of the pandemic in South Africa:

'We've been liaising with city of Cape Town and with Western province government. evidence is that we hosted the hospital of hope so, you know, we build the hospital of hope, over the time period, with the support of the Western Cape government's health department.'

Since venues sell space, they have responded to COVID-19 by diversifying their operations during the pandemic, particularly during a period in which business travel could not occur. Considering that the above example describes a venue that had been purposely built for MICE events, it left very little opportunity to diversify its offering outside of the MICE sector. Accordingly, responses from these venue representatives illustrate that one of the most important steps taken was the implementation of COVID-19 protocols. Encapsulating such views, one respondent expressed the following:

'We've had to reduce the amount of touch points so that they can be an automatic door as guests walk into, they don't have to actually open a door to get into the hotel, that we able to take snapscan that to be able to people don't necessarily need to sign up. If they do sign up, they keep the pin or they sanitse, you know, all those touch points that are so important. and business travellers are looking for that and they're very, very well very quickly say sorry, I don't feel comfortable, I'm not going to do that. And if we've actually got to $100 \%$ understand that and accommodate accordingly.'

The above concurs with the studies affirming that the hospitality industry quickly adapted to the COVID-19 protocols (Lapointe, 2020; Kuscer et al., 2021; Rogerson et al., 2021). In the specific case of South Africa, the Tourism Business Council of South Africa (TBCSA) and the Event Safety Council developed the COVID-19 safety protocols of the tourism and events industry (TBCSA, 2020) which were adopted by several tourism establishments in the country. As explained by the respondents, their adoption of COVID-19 safety protocols not only ensured their compliance but also built confidence (in their markets) to host MICE tourism in their venues. Indeed, one respondent, a representative of an industry association, affirmed that 'we have been the most compliance, we went over and beyond what was required'. Also, many of the venues had further adapted to the virtual events environment, by way of digital upgrades to their facilities. For example, one AV supplier described that '... in partnership with various venues in in Cape Town, Joburg and Durban we actually set up studios and green rooms that would stay there for when lockdown restrictions are eased.' Indeed, there were a few convention centres and other MICE venue suppliers which developed virtual event catalogues, illustrating their capacity to cater for both virtual and hybrid events.

\section{CONCLUSION}

The current study sought to explore the various strategies employed by the MICE sector in response to the COVID19 pandemic in South Africa. The findings revealed that the adaptive strategies employed by the sector included cutting down on operational costs and ensuring that the planned events are rather postponed than cancelled. Additionally, the results illustrated that responses were mostly geared towards adapting to the virtual events environment, which has gained much prominence due to the restrictions implemented in order to manage COVID-19. Adapting to the virtual environment had preempted various responses from different sectors of the MICE industry, with the most common being the change of business strategy to conform to the new environment in which the sector must operate. While the return to in-person events, in the pre-COVID capacities, is still unknown, it can be ascertained that the virtual and hybrid events model adopted during this period will not disappear should there be a relative state of stability.

Instead, these modes of hosting MICE tourism will likely feature in the post-COVID-19 world, particularly as they had opened up some opportunities for expanding new markets and offered some continuity during periods of uncertainty. In this regard, the resilience theory had been instrumental in grounding the current study, as it enabled the understanding of the change occurring in the sector. As such, the study provides some theoretical contributions to literature, as it broadens the scope of literature on MICE tourism and COVID-19, particularly in the developing nations context. Furthermore, it moves away from examining the impacts of the pandemic to exploring the process of change in MICE tourism, and potentially the process of sector resilience. Notably, the current study is one of the few MICE tourism studies that has adapted the resilience theory thereby extending the applications of the theory.

\section{Acknowledgement}

This article forms part of a doctoral study being conducted at the University of Johannesburg. 


\section{REFERENCES}

Agyeiwaah, E., Adam, I., Dayour, F., \& Baiden, F.B. (2021). Perceived impacts of COVID-19 on risk perceptions, emotions, and travel intentions: evidence from Macau higher educational institutions. Tourism Recreation Research, 46(2), 195-211. https://doi.org/ $10.1080 / 02508281.2021 .1872263$

Alananzeh, O., Al-Badarneh, M., Al-Mkhadmeh, A., \& Jawabreh, O. (2019). Factors influencing MICE tourism stakeholders' decision making: The case of Aqaba in Jordan. Journal of Convention \& Event Tourism, 20(1): 24-43. https://doi.org/10.1080/15470148.2018.1526152

Alsono, A.D., Bressan, A., Kok, A.K., Sakellarios, N., Koresis, A., O’Shea, M., Solis, M.A.B., \& Santoni, A.J. (2021). Facing and responding to the COVID-19 threat - An empirical examination of MSMEs. European Business Review, 33(5), 775-796. https://doi.org/10.1108/EBR-09-2020-0231

Bama, H.K.N., \& Nyikana, S. (2021). The effects of COVID-19 on future domestic travel intentions in South Africa: A stakeholder perspective. African Journal on Hospitality, Tourism and Leisure, 10(1), 179-193. https://doi.org/10.46222/ajhtl.19770720-94

Bartis, H., Hufkie, B., \& Moraladi, M. (2021). The Economic Impact of the COVID-19 Pandemic on the Business Events Sub-sector in South Africa: Mitigation Strategies and Innovations. African Journal of Hospitality, Tourism and Leisure, 10(1)102-11. https://doi.org/10.46222/ajhtl.19770720-89

Basurto-Cedeno, E., \& Pennington-Gray, L. (2018). An applied destination resilience model. Tourism Review International, $22,293-302$. https://doi.org/10.3727/154427218X15369305779092

Bhamra, R., Dani, S., \& Burnard, K. (2011). Resilience: the concept, a literature review and future directions. International Journal of Production Research, 49(18), 5375-5393. https://doi.org/10.1080/00207543.2011.563826

Biggs, D., Hall, C.M., \& Stoeckl, N. (2012). The resilience of formal and informal tourism enterprises to disasters: reef tourism in Phuket, Thailand. Journal of Sustainable Tourism, 20(5), 645-665. https://doi.org/10.1080/09669582.2011.630080

Buathong, K., \& Lai, P. (2017). Perceived attributes of event sustainability in the MICE industry in Thailand: A viewpoint from governmental, academic, venue and practitioner. Sustainability, 9(7), 1151. https://doi.org/10.3390/su9071151

Bueno, A.R., Urbistondo, P.A., \& Martínez, B.A. (2020). The MICE tourism value chain: Proposal of a conceptual framework and analysis of disintermediation. Journal of Convention \& Event Tourism, 21(3): 177-200. https://doi.org/10.1080/15470148.2020.1740851

Cassar, J., Whitfield, J., \& Chapman, A. (2020). Contemporary factors influencing association conference attendance. Journal of Convention \& Event Tourism, 21(1), 57-90. https://doi.org/10.1080/15470148.2020.1719948

Cheng, L., \& Zhang, J. (2020). Is tourism development a catalyst of economic recovery following natural disaster? An analysis of economic resilience and spatial variability. Current Issues in Tourism. https://doi.org/10.1080/13683500.2019.1711029

Chowdhury, M., Prayag, G., Orchiston, C., \& Spector, S. (2019). Post-disaster Social Capital, Adaptive Resilience and Business Performance of Tourism Organizations in Christchurch, New Zealand. Journal of Travel Research, 58(7), 1209- 1226. https://doi.org/10.1177/0047287518794319.

Christie, I., Fernandes, E., Messerli, H., \& Twining-ward, L. (2013). Tourism in Africa: Harnessing Tourism for Growth and Improved Livelihoods. Washington, DC: The World Bank.

Clement, V., \& Rivera, J. (2017). From adaptation to transformation: An extended research agenda for organisational resilience to adversity in the natural environment. Organization \& Environment, 30(4), 346-365. https://doi.org/10.1177/1086026616658333

Davidson, R., \& Cope, B. (2003). Business travel: Conferences, Incentive travel, exhibitions, corporate hospitality and corporate travel. Harlow: Prentice Hall.

Davidson, R. (2019). Business Events. $2^{\text {nd }}$ Edition. Routledge, London.

Derissen, S., Quaas, M.F., \& Baumgärtner, S. (2011). The relationship between resilience and sustainability of ecological-economic systems. Ecological Economics, 70(6), 1121-1128. https://doi.org/10.1016/j.ecolecon.2011.01.003.

Dillette, A., \& Ponting, S.S. (2021). Diffusing innovation in times of disasters: Considerations for event management professionals. Journal of Convention \& Event Tourism, 22(3):197-220. https://doi.org/10.1080/15470148.2020.1860847

Donaldson, R. (2013). Conference tourism: What do we know about the business tourist in South Africa? African Journal for Physical, Health Education, Recreation and Dance (AJPHERD), 2: 24-38. https://hdl.handle.net/10520/EJC143209

Draper, J., Thomas, L.Y., \& Fenich, G.G. (2018). Event management research over the past 12 years: What are the current trends in research methods, data collection, data analysis procedures, and event types? Journal of Convention \& Event Tourism, 19(1): 3-24. https://doi.org/10.1080/15470148.2017.1404533

Dube, K., Nhamo, G., \& Chikodzi, D. (2021). COVID-19 cripples global restaurant and hospitality industry. Current Issues in Tourism, 24(11), 1487-1490. https://doi.org/10.1080/13683500.2020.1773416

Espiner, S., Orchiston, C., \& Higham, J. (2017). Resilience and sustainability: a complementary relationship? Towards a practical conceptual model for the sustainability-resilience nexus in tourism. Journal of Sustainable Tourism, 25(10), 1385-1400. https://doi.org/10.1080/09669582.2017.1281929

Fenich, G.G. (2008). Meetings, expositions, events, and conventions: An introduction to the industry. (2nd edition). Boston: Prentice Hall.

Fenich, G.G., Hermann, U.P., \& Hashimoto, K. (2012). Toward a framework for development of qualifications in meetings, expositions, events, and conventions in South Africa. Journal of Convention \& Event Tourism, 13(1):39-47. https://doi.org/10.1080/15470148.2012.651783

Fromhold-Eisebith, M. (2015). Sectoral Resilience: Conceptualizing Industry-Specific Spatial Patterns of Interactive Crisis Adjustment. European Planning Studies, 23(9), 1675-1694. https://doi.org/10.1080/09654313.2015.1047329

$\mathrm{Fu}$, Y. (2020). The impact and recovering strategies of the COVID-19 pandemic: Lessons from Taiwan's hospitality industry. Cogent Social Sciences, 6(1):1829806. https://doi.org/10.1080/23311886.2020.1829806

Giddy, J.K., \& Rogerson, M.J. (2021). Nature-Based Tourism Enterprise Adaptive Responses to COVID-19 in South Africa. GeoJournal of Tourism and Geosites, 36(2), 698-707. https://doi.org/10.30892/gtg.362spl18-700

Haywood, M.K. (2020). A post COVID-19 future - tourism re-imagined and re-enabled. Tourism Geographies, 22(3), 599-609. https://doi.org/10.1080/14616688.2020.1762120

Hemmonsbey, J., Tichaawa, T.M., \& Knott, B. (2021). Strategic conceptualisation of the South African Sport Tourism Sector's Response to the COVID-19 pandemic. African Journal on Hospitality, Tourism and Leisure, 10(1), 54-68. https://doi.org/10.46222/ajhtl.19770720-86.

Ho, J.M., \& Sia, J.K.M. (2020). Embracing an uncertain future: COVID-19 and MICE in Malaysia. Local Development \& Society, 1(2), 190-204. https://doi.org/10.1080/26883597.2020.1818533

Jaaron, A.A., Pham, D.T., \& Cogonon, M.E. (2021). Systems thinking to facilitate "double loop" learning in tourism industry: a COVID19 response strategy, Journal of Sustainable Tourism, https://doi.org/10.1080/09669582.2021.1948554

Jago, L., \& Deery, M. (2010). Delivering innovation, knowledge and performance: The role of business events, Accessed 01 July 2020. https://www.businesseventscouncil.org.au/files/BE_Innov_Report_Mar10.pdf

Kato, K. (2018). Debating Sustainability in Tourism Development: Resilience, Traditional Knowledge and Community: A Post-disaster Perspective. Tourism Planning \& Development, 15(1): 55-67. https://doi.org/10.1080/21568316.2017.1312508

Kaufmann, M. (2013). Emergent self-organisation in emergencies: Resilience rationales in interconnected societies. Resilience, 1(1), 5368. https://doi.org/10.1080/21693293.2013.765742 
Knight-Lenihan, S. (2016). Benefit cost analysis, resilience and climate change. Climate Policy, 16(7), 909-923. https://doi.org/10. 1080/14693062.2015.1052957

Korinth, B., \& Ranasinghe, R. (2020). COVID-19 Pandemic's Impact on Tourism in Poland in March 2020. GeoJournal of Tourism and Geosites, 31(3), 987-990. https://doi.org/10.30892/gtg.31308-531

Kuscer, K., Eichelberger, S., \& Peters, M. (2021). Tourism organizations' responses to the COVID-19 pandemic: An investigation of the lockdown period. Current Issues in Tourism, 1-14. https://doi.org/10.1080/13683500.2021.1928010

Lapointe, D. (2020). Reconnecting tourism after COVID-19: the paradox of alterity in tourism areas. Tourism Geographies. https://doi.org/10.1080/14616688.2020.1762115

Lew, A.A. (2014). Scale, change and resilience in community tourism planning. Tourism Geographies, 16(1), 14-22. https://doi.org/10.1080/14616688.2013.864325

Marais, M., du Plessis, E., \& Saayman, M. (2017). Critical success factors of a business tourism destination: Supply side analysis. Acta Commercii - Independent Research Journal in the Management Sciences, 17(1): 1-12. http://dx.doi.org/10.4102/ac.v17i1.423.

Marques, J., \& Pinho, M. (2020). Collaborative research to enhance a business tourism destination: A case study from Porto. Journal of Policy Research in Tourism, Leisure and Events. https://doi.org/10.1080/19407963.2020.1756307

Matei, D., Chiriță, V., \& Lupchian, M.M. (2021). Governance and Tourism Resilience during the COVID-19 Crisis. Case Study Bukovina, Romania. GeoJournal of Tourism and Geosites, 34(1), 256-262. https://doi.org/10.30892/gtg.34135-646

Matiza, T., \& Slabbert, E. (2021). Tourism is too dangerous! Perceived risk and the subjective safety of tourism activity in the era of COVID-19. GeoJournal of Tourism and Geosites, 36(2), 580-588. https://doi.org/10.30892/gtg.362spl04-686

Mensah, E.A., \& Boakye, K.A. (2021). Conceptualizing Post COVID 19 Tourism Recovery A Three Step Framework. Tourism Planning \& Development, https://doi.org/10.1080/21568316.2021.1945674

Nguyen, D.N., Esteban, M., \& Motoharu, O. (2021). Resilience adaptive capacity wheel: Challenges for hotel stakeholders in the event of a tsunami during the Tokyo Olympics. International Journal of Disaster Risk Reduction, 55, 102097. https://doi.org/10.1016/j.ijdrr.2021.102097

Nicula, V., \& Elena, P.R. (2014). Business Tourism Market Developments. Procedia Economics and Finance, 16, $703-712$. https://doi.org/10.1016/S2212-5671(14)00858-2

Ntounis, N., Parker, C., Skinner, H., Steadman, C., \& Warnaby, G. (2021). Tourism and Hospitality industry resilience during the Covid19 pandemic: Evidence from England. Current Issues in Tourism, 1-14. https://doi.org/10.1080/13683500.2021.1883556

Nyawo, J.C. (2020). Evaluation of government responses and measures on COVID-19 tourism sector: A case of tour guides in South Africa. African Journal on Hospitality, Tourism and Leisure, 9(5), 1144-1160. https://doi.org/10.46222/ajhtl.19770720-74.

Pearlman, D.M., \& Gates, N.A. (2010). Hosting business meetings and special events in virtual worlds: a fad or the future?. Journal of Convention \& Event Tourism, 11, (4), 247-265. https://doi.org/10.1080/15470148.2010.530535

Quang, T.D., Tran, T.C., Tran, V.H., Nguyen, T.T., \& Nguyen, T.T. (2020). Is Vietnam ready to welcome tourists back? Assessing COVID-19's economic impact and the Vietnamese tourism industry's response to the pandemic. Current Issues in Tourism, https://doi.org/10.1080/13683500.2020.1860916

Rogerson, C.M. (2015). Unpacking business tourism mobilities in sub-Saharan Africa. Current Issues in Tourism, 18(1): 44-56. https://doi.org/10.1080/13683500.2014.898619

Rogerson, C.M., \& Baum, T. (2020). COVID-19 and African tourism research agendas. Development Southern Africa, 37(5), $727-741$. https://doi.org/10.1080/0376835X.2020.1818551

Rogerson, C.M., \& Rogerson, J.M. (2021). COVID-19 and changing tourism demand: Research review and policy implications for South Africa. African Journal on Hospitality, Tourism and Leisure, 10(1), 1-21. https://doi.org/10.46222/ajhtl.19770720-83.

Rogerson, J.M., Lekgau, R.J., Mashapa, M.M., \& Rogerson, C.M. (2021). Covid-19 and local business responses: Evidence from South Africa's most tourism-dependent locality. African Journal of Hospitality, Tourism and Leisure, 10(1), 388-405. https://doi.org/10.46222/ajhtl.19770720-107.

Rogerson, J.M. (2021). Tourism Business Responses to South Africa's COVID-19 Pandemic Emergency. GeoJournal of Tourism and Geosites, 35(2), 338-347. https://doi.org/10.30892/gtg.35211-657

Seraphin, H. (2021). COVID-19: An opportunity to review existing grounded theories in event studies. Journal of Convention \& Event Tourism, 22(1):3-35. https://doi.org/10.1080/15470148.2020.1776657

Sigala, M. (2020). Tourism and COVID-19: Impacts and implications for advancing and resetting industry and research. Journal of Business Research, 117, 312-321. https://doi.org/10.1016/j.jbusres.2020.06.015.

Steriopoulos, E., \& Wrathall, J. (2021). Re-imagining and transforming events: Insights from the Australian events industry. Research in Hospitality Management, 11(2):77-83. https://doi.org/10.1080/22243534.2021.1917809

Su, D.N., Tra, D.L., Huynh, H.M.T., Nguyen, H.H.T., \& O’Mahony. B. (2021). Enhancing resilience in the Covid 19 crisis lessons from human resource management practices in Vietnam. Current Issues in Tourism, https://doi.org/10.1080/13683500.2020.1863930

Tichaawa, T.M. (2017). Business tourism in Africa: The case of Cameroon. Tourism Review International, 21, $181-192$. https://doi.org/10.3727/154427217X14939227920829

Tomaszewski, L.E., Zarestky, J., \& Gonzalez, E. (2020). Planning Qualitative Research: Design and Decision Making for New Researchers. International Journal of Qualitative Methods. https://doi.org/10.1177/1609406920967174

Tourism Business Council of South Africa (TBCSA). (2020). TBCSA Presents Calculated, Driven and Gradual Re-Opening of Tourism to Parliament's Tourism Portfolio Committee. Accessed 12 June 2020. https://tbcsa.travel/tbcsa-presents-calculated-driven-andgradual-re-opening-of-tourism-to-parliaments-tourism-portfolio-committee/

Wang, F., Xue, T., Wang, T., \& Wu, B. (2020). The mechanism of tourism risk perception in severe Epidemic - The antecedent effect of place image depicted in anti-epidemic music videos and the moderating effect of visiting history. Sustainability, 12(13):5454. https://doi.org/10.3390/su12135454.

Westmattelmann, D., Grotenhermen, J.G., Sprenger, M., \& Schewe, G. (2021). The show must go on-virtualisation of sport events during the COVID-19 pandemic. European Journal of Information Systems, 30(2), 119-136. https://doi.org/10.1080/0960085X.2020.1850186

*** Events Council Industry. (2020). Global economic Significance of Business Events. Washington, DC.

*** Government of South Africa. (2021). Coronavirus COVID-19 Alert levels Accessed 20 June 2020.https://www.gov.za/covid19/about/coronavirus-covid-19-alert-level-1

*** South Africa Travel Trade (May, 2020). MICE Sector - Webinar. Accessed 22 May 2020. https://www.youtube.com/watch?v=m KNUKRJojkE\&t=2677s

*** United Nations World Tourism Organisation (UNWTO). (2020). International Tourism Arrivals Could Fall by $20-30 \%$ in 2020. Madrid: UNWTO 